\title{
Vitus Bering (1681-1741)
}

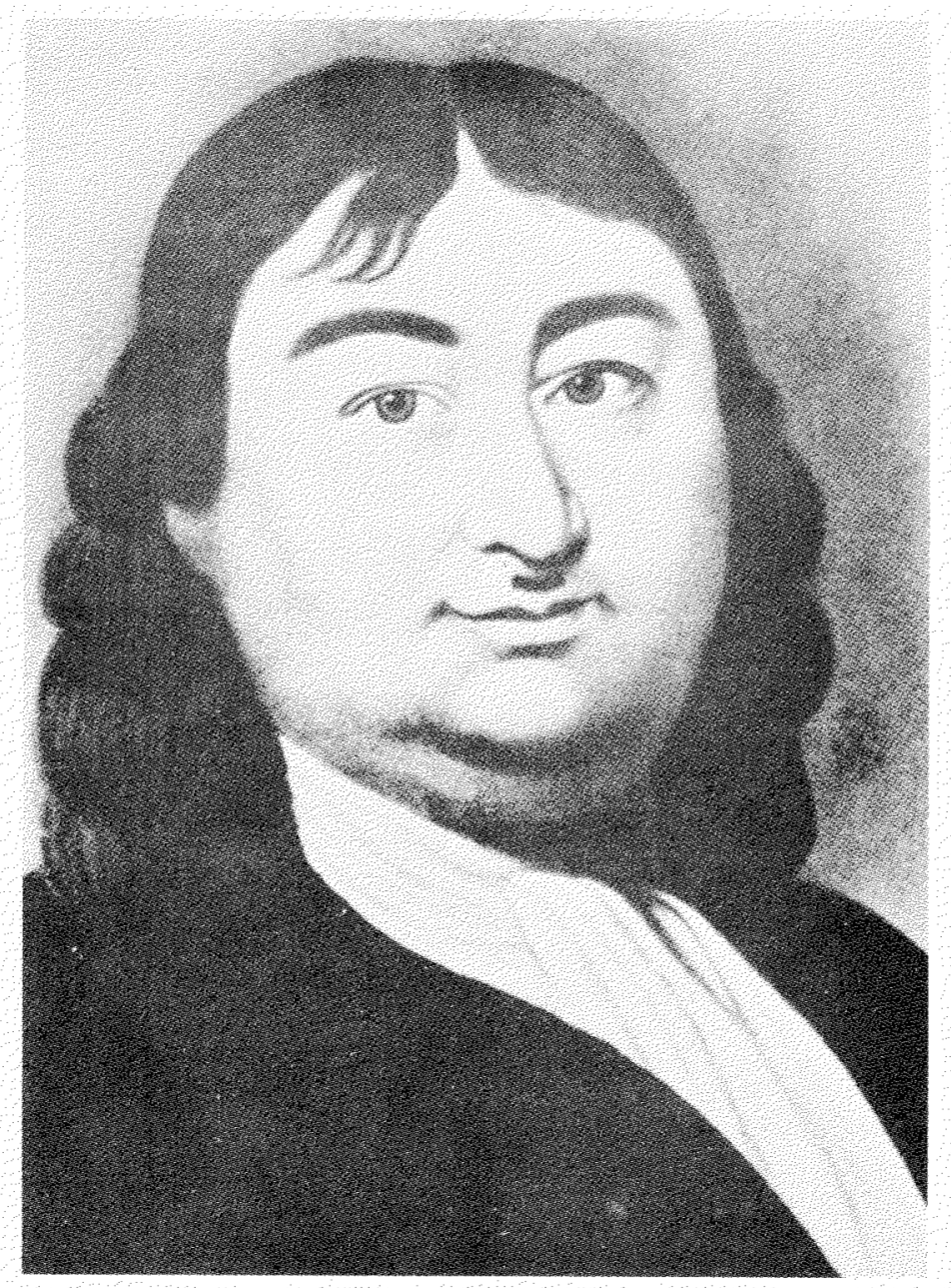

The navigator and explorer Captain Commander Vitus Jonassen (in Russian, Ivan Ivanovich) Bering was one of many foreign specialists brought to Russia by Tsar Peter the Great in order to help modernize the growing but lagging empire. He is known principally for his two voyages of exploration and discovery in the second quarter of the eighteenth century, the first to Bering Strait - which he did not personally discover - and the other to the Gulf of Alaska.

Bering was a native of Denmark, where he was born on 12 August 1681 in the Jutland seaport of Horsens. Very little is known of his upbringing or personality. He was fairly well educated, and well mannered and devout. As a commander he was cautious and unhurried, and he seems to have been liked for his gentleness and humility.

By the time Bering was invited by Admiral Cruys in 1703 to join the fledgling Russian Navy as a sublieutenant, he had already voyaged to the East Indies. Apparently he acquitted himself quite satisfactorily in Russia's naval campaigns in the Baltic, Black, and White seas, as he was promoted to lieutenant in 1707 , captain lieutenant in 1710 , and captain (second class) in 1720. In 1723 he requested promotion to captain (first class) but was refused, and he resigned to live on an estate at Vyborg.

Meanwhile, the thoroughgoing and draconian transformation of Muscovy by Peter the Great along Western lines included not only the creation of a respectable navy but the extension of Russian geographical knowledge and political dominion. The lands and waters of the far North Pacific - still unexplored and unsettled by European powers had long interested the inquisitive and versatile tsar, who now decided to satisfy his scientific curiosity and imperial appetite with a secret expedition. Bering's lengthy naval experience was brought to Peter's attention by Admiral Apraksin, who persuaded the retired veteran to re-enlist in 1724 at the rank of captain (first class) and take charge of the 100-man First Kamchatka Expedition, 1725-1729.

The tsar's personal instructions, penned only two days before his death, were not handed to Bering until the very day of his departure from St. Petersburg. This was done deliberately in order to minimize publicity, for xenophobic Russia with its national inferiority complex feared that its Western European imperial rivals might beat it to the terra incognita of northwestern America. Bering was directed 
to build one or two ships in Kamchatka, sail northwards through the Otter (Bering) Sea, determine whether Asia and America were separated, go ashore and make a firsthand report and a map, and contact any European settlement or ship to learn the name of the locale. The third point was a ruse to mask the expedition's real purpose, namely, to probe the American coast; Peter the Great had known since the end of the previous century that Semyon Dezhnev had sailed between the two continents in 1648 . But Bering followed his instructions and navigated Anian (Bering) Strait as far north as $67^{\circ} 18^{\prime}$ in 1728 , discovering St. Lawrence Island and the two Diomedes. The next year he sailed eastwards from Kamchatka for three days but found no land. Upon his return to the imperial capital he was promoted to captain commander and awarded 1000 silver rubles.

Neither Bering nor the government was satisified with the results of the expedition, the latter because it had not reached America and the former because he was aware of how much exploration remained undone. So at Bering's suggestion the Second Kamchatka Expedition, 1733-1742, was mounted, again under his command. It was one of three components of the grandiose Great Northern Expedition, one of the most ambitious and expensive undertakings in the history of exploration and discovery. Charged with surveying the northern and eastern coasts of Siberia from the Northern Dvina to the Amur and probing Japan and America, it comprised 13 ships and some 3000 men, including many savants from the infant Academy of Sciences (notably Germans like Gerhard Müller, Georg Steller, and Johann Gmelin). This second expedition was even more onerous and protracted than the first, of course. Bering left St. Petersburg at the beginning of 1733 but did not embark from Okhotsk, Siberia's chief Pacific port, until September of 1740 , because of the enormous distance and staggering difficulties of transport, the obstacles to shipbuilding at Okhotsk, bureaucratic delays, personality clashes, and jurisdictional disputes. Finally, the springboard of Kamchatka was reached and a new base, Petropavlovsk, named after the expedition's two packetboats, the St. Peter and St. Paul, was founded on superb Avacha Bay.

The two vessels sailed in June 1741 , heading southeastwards at first in order to locate the imaginary De Gama Land. After two weeks they were permanently separated by a storm, but both continued eastwards and made landfalls on the Gulf of Alaska coast in July (15 well-armed men from the St. Paul under Captain Aleksey Chirikov went ashore and never returned). On the return passage some of the Aleutian and other islands were discovered. The rickety St. Peter with its scorbutic crew was wrecked on Avacha (Bering) Island in the Commander group. There the survivors wintered, but several, including the elderly Bering on 6 December, died of scurvy and hypothermia. The following summer the stragglers fashioned a vessel from the remains of the St. Peter and made Petropavlovsk to rejoin Chirikov, who had returned safely the previous fall.

At last, Bering had accomplished his mission, albeit at the cost of his own life. He had sighted and reconnoitered the "big land", and thereby laid the basis for a Russian claim and paved the way for further Russian exploration and settlement. He also introduced a source for future profits in the 2000 sea otter pelts brought back by his expedition. They triggered a fur rush down the Kuriles and across the Aleutians to Alaska and the Northwest Coast, eventually culminating in the establishment of Russian America and the Russian-American Company in 1799. Thus was realized Peter the Great's original plan of extending his country's eastward drive for new fur sources as the sables and foxes of Siberia were depleted. The treasury's share of income from this lucrative industry was essential to help finance the tsar's costly foreign compaigns and domestic reforms.

\section{FURTHER READINGS}

FISHER, RAYMOND H. 1977. Bering's Voyages: Whither and Why. Seattle: University of Washington Press.

GOLDER, FRANK A. 1922-25. Bering's Voyages. 2 vols. New York: American Geographical Society.

LAURIDSEN, PETER. 1889. Vitus Bering: The Discoverer of Bering Strait. Trans. by Julius E. Olson. Chicago: S.C. Griggs \& Company.

POLEVOY, B.P. 1982. (In press). The Three Hundredth Anniversary of the Birth of Vitus Bering. Trans. by James R. Gibson. Polar Geography and Geology 6.

WAXELL, SVEN. 1962. The Russian Expedition to America. Trans. by M.A. Michael. New York: Collier Books.
James R. Gibson
Department of Geography
York University
Downsview, Ontario, Canada
M3J 1P3 